\title{
THE ROLE AND IMPORTANCE OF THE LANDSCAPE PARK UDIN BORŠT
}

Mateja Šmid Hribar, Mateja Ferk

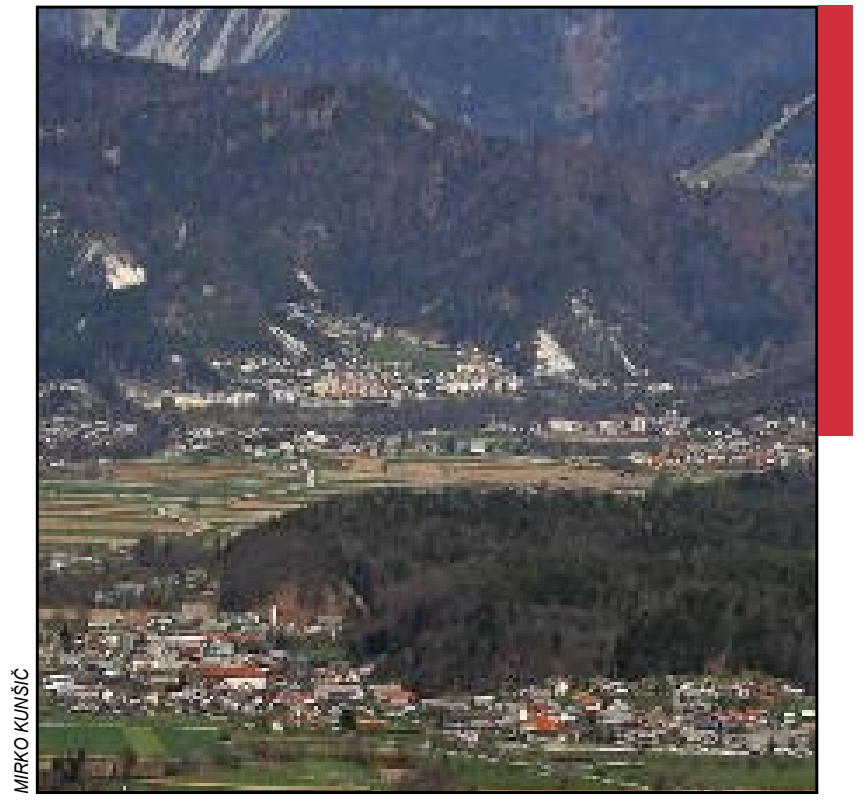

Northwest part of the Landscape park Udin Boršt with the settlemet Duplje. 


\title{
The role and importance of the landscape park Udin Boršt
}

\author{
DOI: http://dx.doi.org/10.3986/AGS.968 \\ UDC: 913:551.44(497.4Udin boršt) \\ 719(497.4Udin boršt) \\ COBISS: 1.01
}

\begin{abstract}
Udin Boršt is an isolated conglomerate terrace in Gorenjska region, Slovenia. A number of surface karst features and caves developed here due to the predominance of carbonate gravel. It is one of the last contiguous areas of lowland forest in Gorenjska region, and a popular recreation location for the people living nearby. Due to its karst surface and the forest it offered shelter to the locals in turbulent times. Its role during the period when bandits (rokovnjači) was common and during the Second World War is still preserved in folk memory. Due to its natural and cultural heritage, the area was protected as a Memorial park in 1985, but the legislation has become outdated and needs to be amended and updated. This article presents new findings on the geomorphological and intangible cultural heritage that need to be incorporated in the amended legislation.
\end{abstract}

KEY WORDS: geography, conglomerate karst, isolated karst, eogenetic karst, shallow karst, geomorphological heritage, cultural heritage, landscape park, Udin Boršt

The article was submitted for publication on October $9^{\text {th }}, 2014$.

ADDRESSES:

Mateja Šmid Hribar, Ph.D.

Anton Melik Geographical Institute

Research Centre of the Slovenian Academy of Sciences and Arts

Gosposka ulica 13, SI - 1000 Ljubljana, Slovenia

E-mail: mateja.smid@zrc-sazu.si

Mateja Ferk, Ph.D.

Anton Melik Geographical Institute

Research Centre of the Slovenian Academy of Sciences and Arts

Gosposka ulica 13, SI - 1000 Ljubljana, Slovenia

E-mail: mateja.ferk@zrc-sazu.si 


\section{Introduction}

The Udin Boršt (Duke's forest) is an isolated conglomerate glacial terrace rising up to $50 \mathrm{~m}$ above the gravel plain Gorenjske Dobrave (Woodland of Upper Carniola) and measuring approximately $15 \mathrm{~km}^{2}$. It is one of the last contiguous areas of lowland forest in Gorenjska region (Upper Carniola), which makes it increasingly popular among both locals and visitors.

A morphologically heterogeneous landscape developed due to the geological characteristics of the conglomerate rock (Grad and Ferjančič 1976; Žlebnik 1978). The wide range of landforms creates an area with a high degree of geodiversity. The assessment of the geodiversity of Udin Boršt was conducted by the methodological approach suggested by Bojan Erhartič to whom we dedicate this paper. Furthermore, the natural features turned Udin Boršt into an important shelter for locals during foreign invasions. In order to commemorate the importance of this area, especially during the Second World War, and its natural and cultural heritage, the Udin Boršt was protected as a Memorial park in 1985 (Odlok o razglasitvi ... 1985).

This study focuses on the modern role of the Udin Boršt and whether it complies with the criteria and values based on which it was protected. Because the monument protection ordinance is outdated and must be redefined due to the newly established Municipality of Naklo, the importance of protecting the Udin Boršt is analysed from the viewpoint of new functions and findings.

\section{Methods}

The research included a detailed study of literature and legislation on nature and cultural protection, and a field inspection of natural and cultural heritage. In order to obtain numerical data on the Udin Boršt geomorphological heritage (Panizza 2001), a quantitative Swiss method (Reynard et al. 2007) was used to evaluate the landforms. This method is based on simplified evaluation criteria divided by importance, which renders the procedure more transparent and makes the results suitable for the academic, professional, and nature protection community (Erhartič 2010). The conglomerate karst of the Udin Boršt was treated as a homogenous geomorphological landscape unit, which was compared to all of Slovenia. The criteria used include (1) scientific value: assessment of rareness, representativeness, integrity, and paleogeographic value, and (2) additional values: assessment of ecological value (ecological impact and protected sites), aesthetic value (view points, and contrast), cultural value (religious importance, historical importance, artistic and literary importance, and geo-historical importance), and economic value (qualitative and quantitative). The assessment of additional values also included a planning value. A five-point scale was used for the evaluation; the scale was adapted in such a way that at the same time the results also show individual shares ( $100 \%$ being the highest theoretical score). Each criterion was ascribed a value between 0 (no value) and 100 (extremely high value) and the following scores: $0,25,50,75$, and 100 .

The social and recreational role of the Udin Boršt was evaluated using a quantitative method; that is, two chronicles published by the local Cultural and tourism society Pod krivo jelko Duplje (hereinafter: CTS Pod Krivo jelko Duplje; Pod Krivo jelko means under the bent fir tree) (Kronika KTD Pod krivo jelko Duplje 1997-2009; Kronika KTD Pod krivo jelko Duplje 2009-2012) and the visitors' book (Vpisna knjiga 2012). Entries for the 2003-2012 were taken into account, and visits in 2012 were analysed in greater detail in order to determine the number of places and countries the visitors come from.

\section{Geomorphological heritage of the conglomerate karst of Udin Boršt}

During Quaternary the Sava river and its tributaries deposited large amounts of gravel and finer sediments in central Gorenjska region that formed the conglomerate rocks (Grad and Ferjančič 1976). From the genetic viewpoint, the conglomerate of Udin Boršt is in the stage of early diagenesis or eogenetic stage (Lipar and Ferk 2011; Ferk and Lipar 2012). The poorly cemented conglomerates initiate dynamic processes and fast development of the geomorphological system that results in a great number and variety of geomorphological features.

Surface and subsurface karst features developed in the western and central part of the Udin Boršt, and a fluvial geomorphological system developed in its eastern part. Dolines predominate among surface geomorphological karst features. They are usually up to $10 \mathrm{~m}$ deep and tens of meters in diameter. The largest 
among them are 20 to $30 \mathrm{~m}$ deep, and can measure as much as $100 \mathrm{~m}$ in diameter. The dolines are filled with fine-grained sediments that are relatively flattened. Suffosion depressions are smaller than dolines. These are funnel-shaped holes in unconsolidated regolith or alogenic detritus covering the conglomerate that form when the sediments are washed into the underlying karstified bedrock. They are up to $5 \mathrm{~m}$ wide and $5 \mathrm{~m}$ deep. In some places, erosion gullies formed on the slopes of suffosion depressions. The water that occasionally runs through them sinks to the underground at the lowest point of the depressions. North of Strahinj a $500 \mathrm{~m}$ long blind valley is formed, stretching in the north-south direction. Its uppermost part begins with several steep gullies that join into an increasingly wider valley. In its lower part, the bottom of the blind valley expands into a $40 \mathrm{~m}$ wide plain enclosed by steep slopes. At the edge of the plain several ponors are formed through which the intermittent brook sinks into the karst underground. The water percolates through the voids in the conglomerate to the underground water table, whereby it dissolves the rock, widens the flow channels, and forms caves. Udin Boršt has an autogenic recharge entirely through precipitation water, and the water flows diffusely to numerous karst springs on the edges of the terrace. At some springs, pocket valleys (Lipar and Ferk 2015) formed in the upstream ends. The two longest ones are near Duplje, where the Dupeljščica River springs from Arneš Cave, and near Strahinj, where the Lebinica River springs from Velika Lebinca Cave.

\section{Historical aspects}

Except for the rare forts dating back to the Iron age and the defence posts from classical antiquity, there is no other evidence of this area being settled. The first villages were established around the twelfth and thirteenth centuries in the area where the forest meets the fertile plain (Fister 1970). This was also when people began clearing the forest that covered the area north of Kranj.

The Slovenian name Udin Boršt means 'Duke's forest' and the forest was most likely named after Archduke Karl V. (1564-1590), who controlled and managed it (Kranjc 2005). According to Kos (1960, 65), "a boršt is primarily the kind of forest that was excluded or banned from general use. «In the Middle Ages, the forest was only accessible to the castle lords, who used it for hunting. Others could only take wood from it if the duke so allowed. Logging, gathering leaf litter, and picking berries was also strictly limited. Comparing the land use on the Josephinian military map from the second half of the eighteenth century with present-day land use (Figure 1) shows that the area of the Udin Boršt has hardly changed; the only exception is the part in the extreme south that is crossed by the freeway section from Naklo to Kranj. However, the composition of trees has changed significantly: the former oak and hornbeam forest have been replaced by pine (Pinus silvestris) and spruce (Picea abies) (Mulec and Pipan 2005).

The Udin Boršt played an important protective role in the lives of the locals; its caves in particular offered them shelter several times. Valvasor (1689) mentions a large cave in Duplje (most likely Arneš Cave) where the locals hid from the Ottomans and other attackers. In this regard, Vrhovnik (1885) wrote that even at the end of the nineteenth century the Boltar farm in Duplje still had an iron gate that was believed to have been used to close the entrance to Arneš Cave. Caves were also important hiding places from 1825 to 1853 , when bandits (rokovnjači) lived in the Udin Boršt. These were young men that did not want to serve in the military and preferred to hide in the forest. Sometimes they were also joined by women. They gathered and got married by the Bent Fir tree (pri Krivi jelki), where they also held fests called finfranje (Bohinjec 1998). During the Second World War in Yugoslavia, the Udin Boršt was one of the centres of the partisan movement in Gorenjska Region.

\section{Social and recreational role}

The social and recreational role of the Udin Boršt is becoming increasingly important. Several tourism and cultural societies are active in this area, which also include the Udin Boršt in their programs. The CTS Pod krivo jelko Duplje is based in the settlement Duplje. Because the original Bent fir tree where bandits 


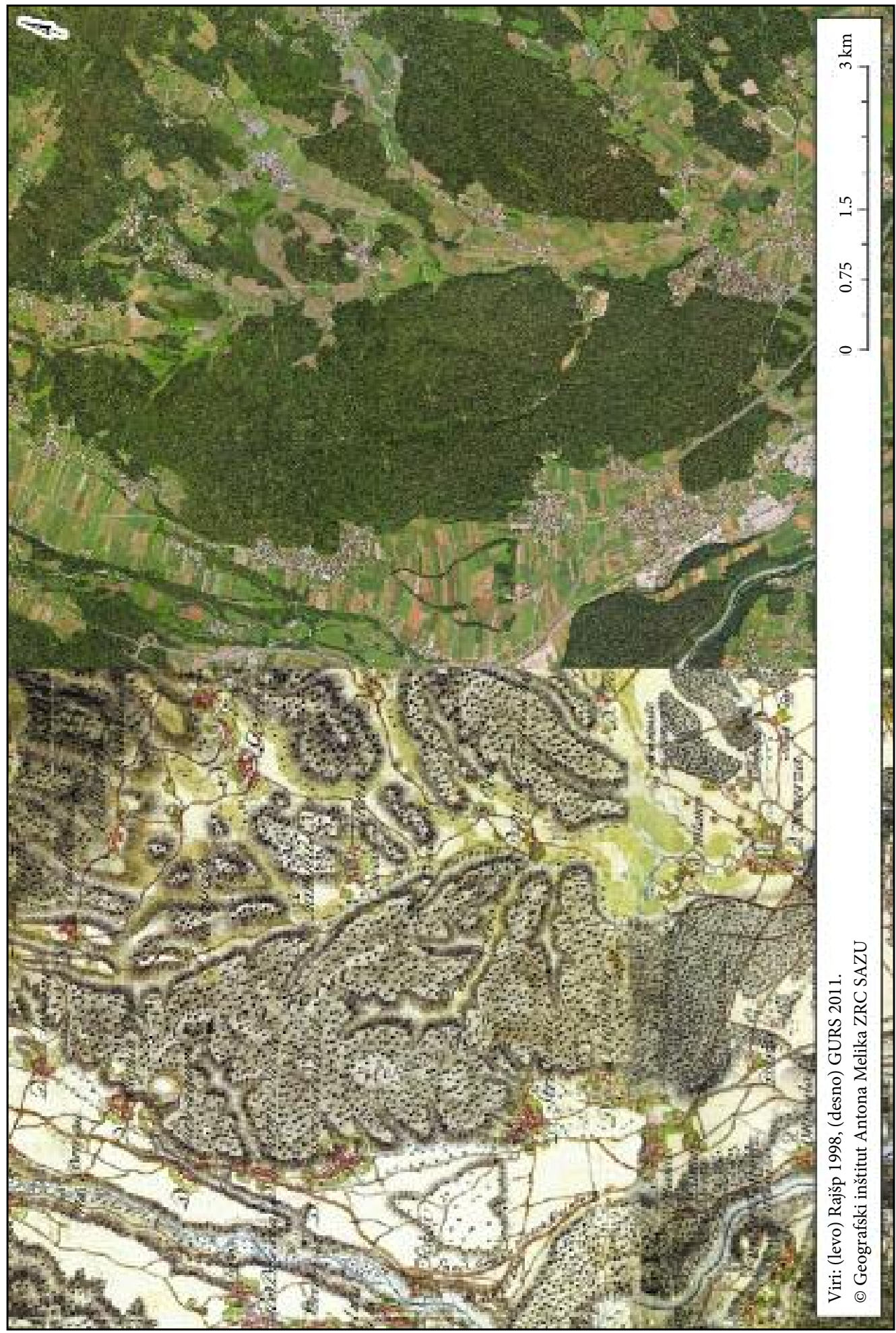


used to gather was felled by snow more than a century ago, the two oldest Duplje residents planted a substitute one in 1998 at the society's initiative (Šmid Hribar 2009). The society holds an annual torch-lit night walk on the first Saturday in January. Participants gather by the fir, where they are greeted by boiled potatoes, lard, tea, and mulled wine. The society also holds a bandits' fest in May, which is also when a »Bandits' run« takes place. The "Duplje orienteering route and the "Bent fir tree loop trail« in the Udin Boršt were also set up as part of the society's activities (Kuhar and Šmid 2002); in 2012, this loop grew into the »Conglomerate karst land hiking trail« (Pešpot ... 2013).

An important role is also played by the Udin Boršt conservation society, which was established in 2007 to prevent the construction of a regional waste-processing centre in Tenetiše. Members of the Kokrica tourism society set up the "Mammoth land trail«, part of which runs past the place called Little mills (Mlinčki) in the southern part of the Udin Boršt, where toy mills are set up along the creek. A walk along the »Three bells trail « has been held in Sebenje every Friday since 2012. The Centre for sustainable rural development Kranj is also becoming an important stakeholder, contributing to the area's development through various projects. In 2012, it set up an »bandit camp with bark tents« near the Bent fir tree, where people can stay the night.

In addition to the locals, people from Kranj and other places in Gorenjska region often visit the Udin Boršt. There are many organizations and active individuals operating in this area, but so far they are fairly unconnected.

\section{Results and discussion: the potential of the Udin Boršt' natural and cultural heritage}

The formal protection that was applied in 1985 points to the unique relationship that the locals had to this area in the past, without which it is likely that the forest would have been cleared significantly more and the area degraded more. However, despite being protected, this area has not received a manager or a management plan in these twenty-eight years. The Udin Boršt memorial park is included in the following two heritage registers (Figure 2):

- In line with the cultural protection legislation, it is inscribed in the Register of immovable cultural heritage (Register nepremične kulturne ... 2014) as a cultural landscape that has the status of a cultural monument of local importance;

- In accordance with nature protection legislation, it belongs to landscape parks (Širša zavarovana območja 2014), and at the same time the isolated karst terrace of the Udin Boršt is inscribed in the Register of natural values as a "surface geomorphological value, subsurface geomorphological value, hydrological value, and geological value of national importance (Pravilnik o določitvi ... 2004).

The 1985 protection ordinance is outdated. In 1994, the new municipality of Naklo was established in this area, but an additional reason for amending the ordinance is also that, despite the fact that The institute of the Republic of Slovenia for nature conservation classifies Udin Boršt under landscape parks, it is currently formally protected only as a memorial park. The new ordinance will have to incorporate new findings in the field of geomorphology and findings connected with the increasingly important social and recreational role of the area, and its intangible heritage, clearly highlighting the purposes and goals of the protection.

Because there is a clear interconnection between natural and cultural heritage in this area, it is recommended that the Udin Boršt be safeguarded as part of the joint protection of monuments and nature in line with Article 15 of the Cultural heritage protection act (2008). Article 60 of this same act requires preparation of a detailed management plan. The new ordinance will have to define the activities allowed in this area, the manager, and his or her responsibilities and tasks, and highlight individual smaller natural and cultural heritage units. The premises of the management plan could be based on the findings of this article. Figure 2 shows the current natural and cultural heritage of the Udin Boršt.

The exceptional opportunity to establish an outdoor laboratory is among the most important scientific prospects for this area. Thanks to the many years of protection, the area's living and non-living nature 
Acta geographica Slovenica, 56-1, 2016

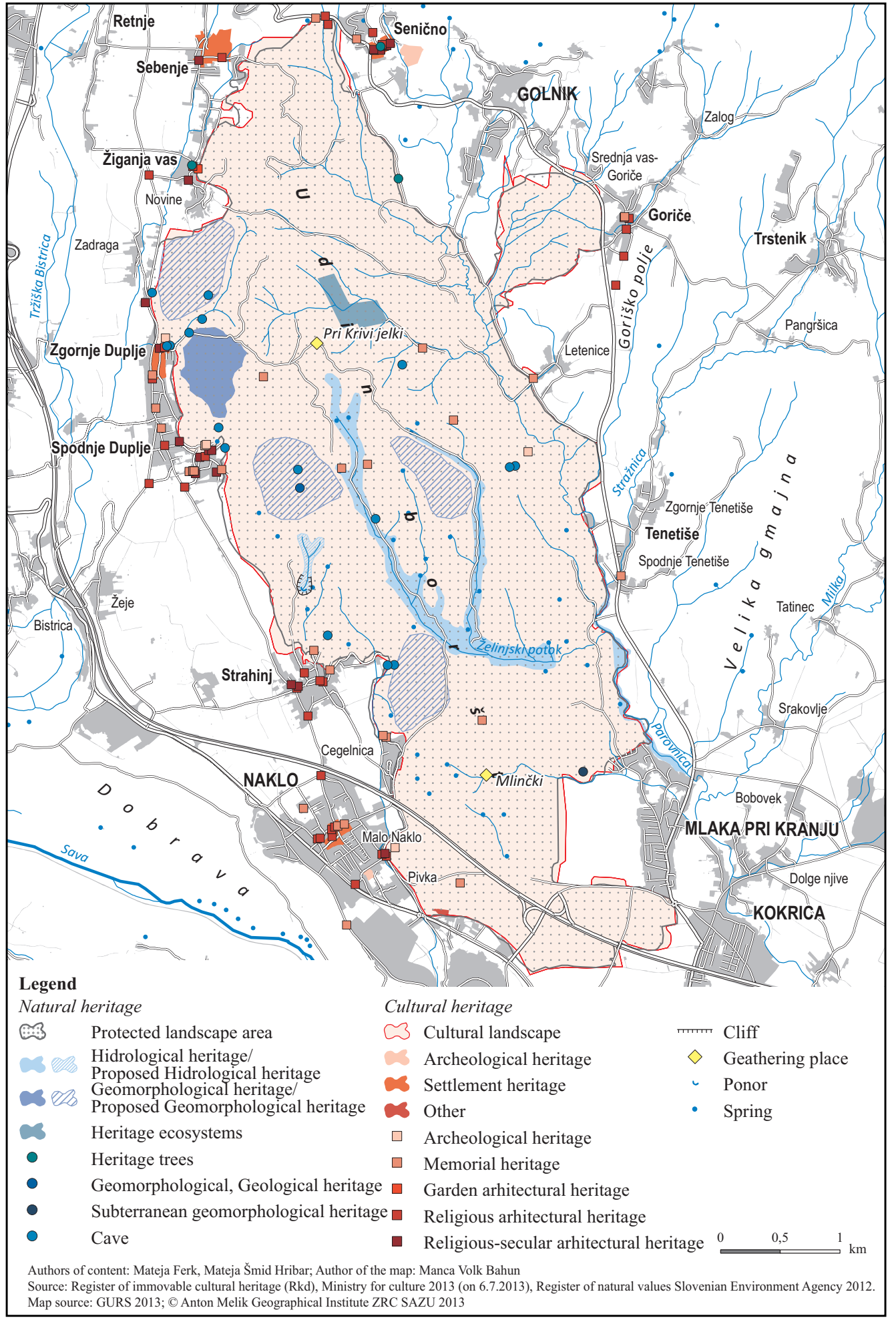


has been preserved well, and at the same time its easy accessibility makes it possible to carry out research and familiarize interested groups with environmental processes in the Udin Boršt. The most important factors for effective protection include education, raising awareness, and participation of locals and visitors in these activities (Polajnar 2008; Smrekar et al. 2011).

\subsection{Natural and geomorphological heritage of the Udin Boršt}

Due to its conglomerate bedrock, a combination of karst and fluvial geomorphological system, and diverse terrain with specific vegetation, the Udin Boršt is an area with a high degree of geodiversity and an important part of geomorphological heritage (Erhartič 2010). The environmental protection significance is increased by the homogeneity of the spatial unit and the density and diversity of its geomorphological features; in the case of Udin Boršt, it would make sense to connect and protect it as a geopark. The karst of Udin Boršt can be defined several ways based on various criteria: as conglomerate or isolated karst (Habič 1981), shallow karst (Žlebnik 1978), or eogenetic karst (Lipar and Ferk 2011; Ferk and Lipar 2012).

Table 1: Quantitative evaluation of the Udin Boršt' geomorphological heritage (Erhartič 2010).

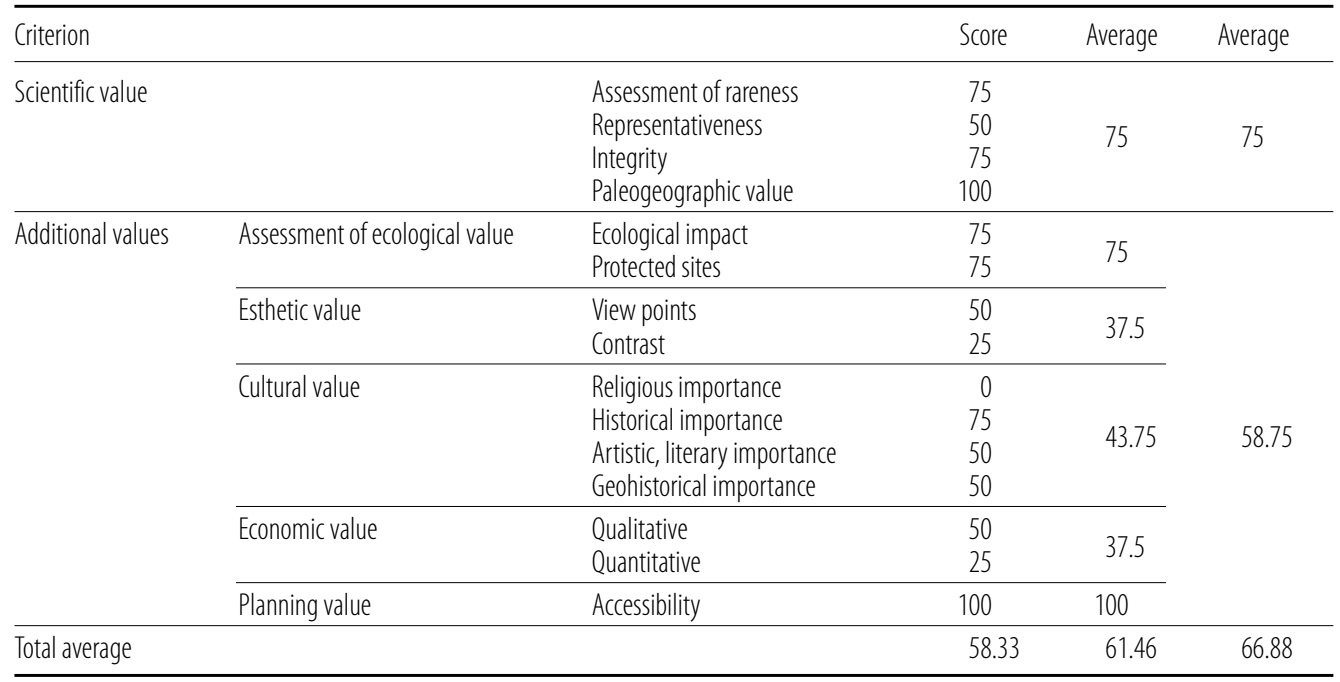

The Udin Boršt has a high average scientific value (75\%) because (1) conglomerate karst is rare in Slovenia, especially in the eogenetic stage of diagenesis; (2) it has many features comparable to classic karst in terms of size; (3) the slightly elevated conglomerate terrace can easily be distinguished from the surrounding area, representing a distinct landscape unit; and (4) it is a richly layered and excellently preserved assembly of information on the palaeoenvironment. The high average ecological value $(75 \%)$ is the result of the many years of protection and the unsuitability of the karst land for agricultural use, which is why the lowland forest with diverse undergrowth has been preserved. The low average esthetic value (37.5\%) is due to forest vegetation, which makes it more difficult to identify the landforms, and the relatively level landscape that reduces visual diversity. The average cultural value (43.75\%) reflects the many centuries of people's connection with the forest, which was often used as a shelter in times of foreign invasions, and the importance of the Udin Boršt' conglomerate karst, based on which eogenetic karst features in continental sediments were defined for the first time (Lipar and Ferk 2011). The low average economic value (37.5\%) results from the fact that the Udin Boršt s' tourism and scientific potential has been underexploited. Accessibility was given the highest score $(100 \%)$ because there is a freeway interchange nearby, and the woods are crisscrossed by roads and contain many well-marked hiking trails. The categories evaluated differ from one another and the authors are aware that they cannot be put on the same level; nonetheless, the sum of all the average scores (scientific and added value) was used to calculate a theoretical total score of the Udin Boršt' geomorphological heritage (67\%) in order to be able to compare it with the scores of other geomorphological heritage sites in the future. 


\subsection{Cultural heritage}

In terms of cultural heritage, the Udin Boršt has already been recognized as a cultural landscape in the past; in addition, the Udin Boršt memorial park contains several archaeological sites and examples of memorial heritage. Architectural and settlement heritage can be found on its edges in the surrounding villages that are inseparably connected with the forest. This is also reflected in rich oral tradition, which is part of intangible heritage. In addition, for several years now the Udin Boršt has been a popular venue for various events (Table 2). In recent years, the Little mills and Bent fir tree meeting points have become the main places for socializing (Figure 3).

Table 2: Events held in the Udin Boršt.

\begin{tabular}{|c|c|c|c|}
\hline Event & Location & Date & Organizer \\
\hline $\begin{array}{l}\text { The Udin Boršt friendship } \\
\text { and memory walk (from Kokrica) }\end{array}$ & Kapnik monument & April 27th (since 1986) & Kokrica Sports Society \\
\hline Bandits'fest (finfranje) & Bent fir tree & Third Saturday in May (since 1998) & CTS Pod Krivo jelko Duplje \\
\hline Torch-lit walk & $\begin{array}{l}\text { From various settlements in } \\
\text { the area to the Bent Fir tree }\end{array}$ & $\begin{array}{l}\text { First Saturday in January } \\
\text { (since 2002) }\end{array}$ & CTS Pod Krivo jelko Duplje \\
\hline $\begin{array}{l}\text { Various walks during Lifelong } \\
\text { Learning Week }\end{array}$ & Various locations in the Udin Boršt & May (since 2004) & CTS Pod Krivo jelko Duplje \\
\hline Mammoth land walk & $\begin{array}{l}\text { From Kokrica past the Little } \\
\text { Mills area }\end{array}$ & September (since 2008) & Kokrica Tourism Society \\
\hline $\begin{array}{l}\text { The Udin Boršt Friendship } \\
\text { and memory walk (from Križe) }\end{array}$ & Kapnik monument & April 27th (since 2009) & $\begin{array}{l}\text { Tržič independence war veterans } \\
\text { organization, Slovenian partisan } \\
\text { veterans league, Tržič municipal } \\
\text { Slovenian officers association }\end{array}$ \\
\hline Three bells walk & $\begin{array}{l}\text { Along the forest trails between } \\
\text { Žiganja Vas, Novaki, and Sebenje }\end{array}$ & $\begin{array}{l}\text { Once a year for large groups, } \\
\text { otherwise every Friday at 6:00 pm, } \\
\text { or 5:00 pm in winter (since 2012) }\end{array}$ & $\begin{array}{l}\text { Sebenje local community and Križe } \\
\text { primary school }\end{array}$ \\
\hline
\end{tabular}
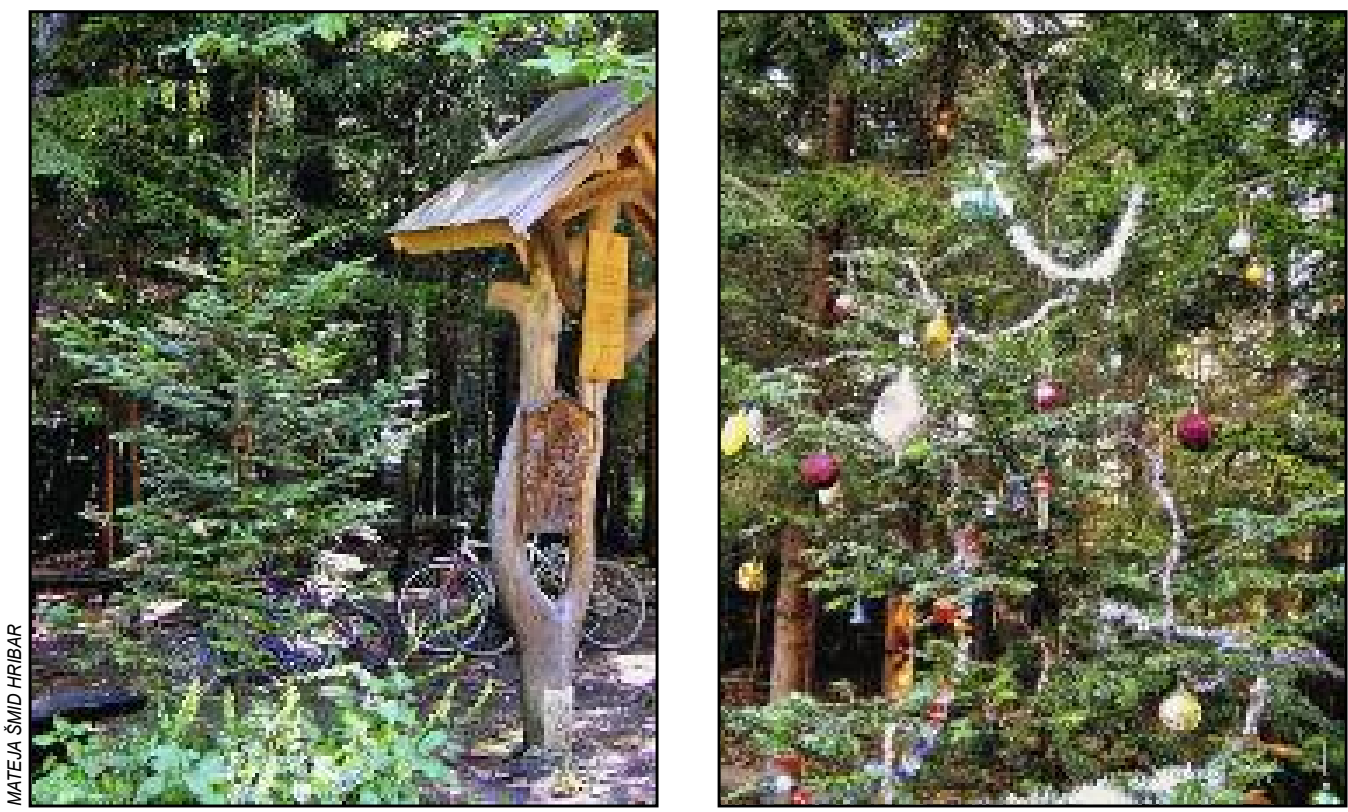

Figure 3: The Bent Fir tree meeting point in the Udin boršt (left) and decorated Bent Fir tree. 


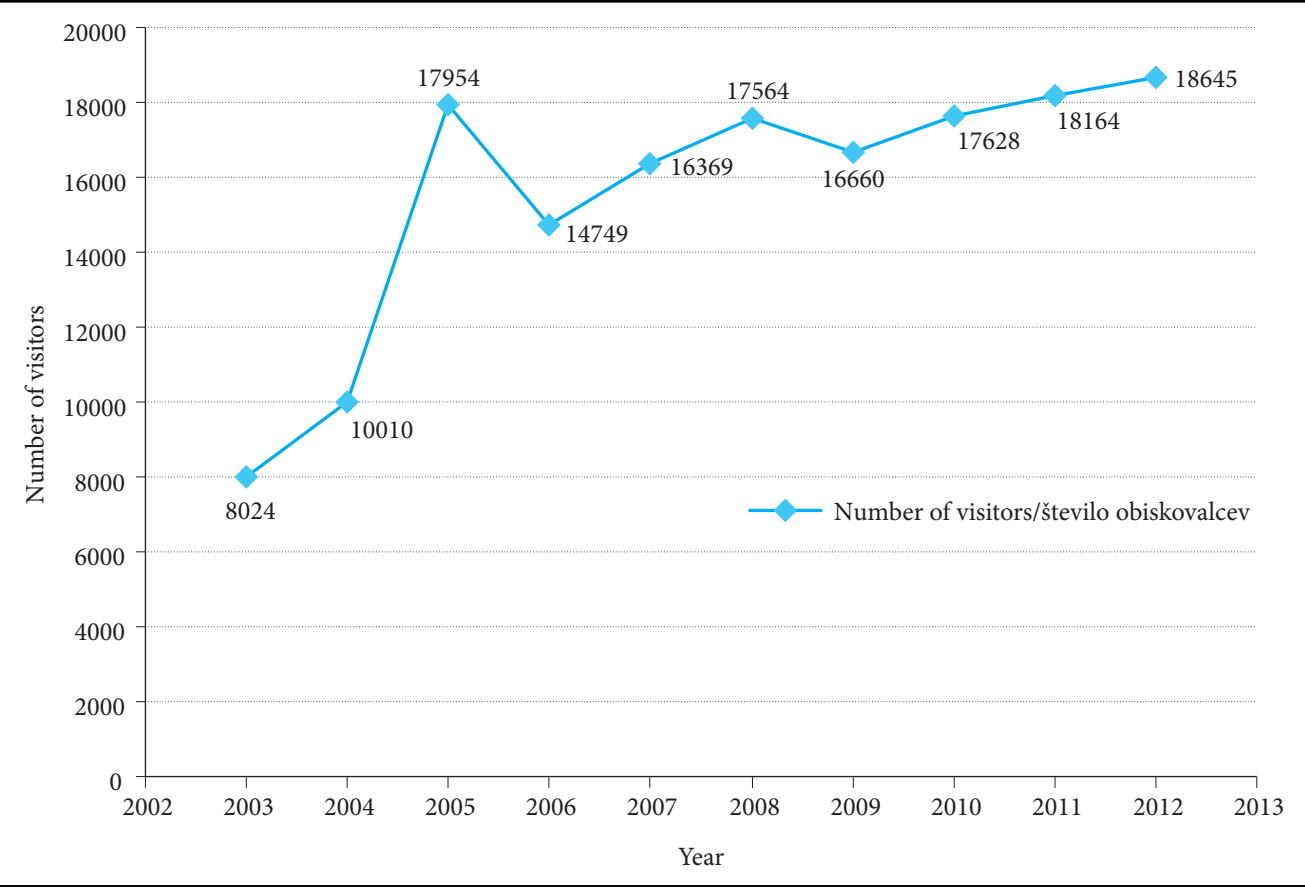

Figure 4: Number of visitors from 2003 to 2012 entered in the Bent fir tree visitors'book (source: Kronika KTD Pod Krivo jelko Duplje 1997-2009; Kronika KTD Pod Krivo jelko Duplje 2009-2012).

Since 2003, visitors have been entering their names in the visitors' book, kept inside a box in the shelter at the Bent Fir tree. Their number has been growing constantly since 2003 (the only exception was 2006; Figure 4). According to the visitors' book (2012), 18,645 people visited the area in 2012; they came from ninety-one places, not only in Slovenia, but also Croatia, Bosnia and Herzegovina, Serbia, Italy, Switzerland, Germany, the Netherlands, Belgium, Canada, and Nicaragua (i.e., ten countries outside Slovenia). On January 1st, 2012 alone, 145 people from thirteen different places visited the Bent fir tree area. Some even celebrate New year's eve there (Vpisna knjiga 2012). Students from the nearby primary schools also visit the Udin Boršt several times a year. They are greeted by »bandits« in the clearing in front of the Bent fir tree.

According to the findings and the UNESCO cultural and natural heritage evaluation criteria (Operational guidelines ... 2013; The Asia ... 1995), it can be concluded that the area has local significance because of:

- Its unique cultural tradition (the 1998 reprint of the story Pod krivo jelko [Under the bent fir tree], which revived interest in the bandits);

- Its direct connection with events or living tradition (oral tradition passed on from one generation to another by people in the nearby villages indirectly influenced the establishment of the CTS Pod Krivo jelko Duplje; the clearing with the new Bent fir tree is visited by more than 18,000 people a year; building the bandit bark tents in the forest; Second World War memorials); and

- The important testimony of the Earth's history and geological processes with regard to the development of landforms (eogenetic karst).

No less important to the wider society is the social and recreational role of the largest contiguous lowland forest in Gorenjska region, which is a popular area for socializing and relaxing.

\section{Conclusion}

The Udin Boršt combines aspects of natural and cultural heritage. The evaluation of the Udin Boršt' geomorphological heritage evaluated according to geomorphosite assesment proposed by Erhartič (2010) shows 
that this area has high scientific and ecological value. The most important but still insufficiently used prospective of this area include its scientific and research potential, with an exceptional opportunity to establish an outdoor laboratory. Direct exchange of researchers' and locals' experience could have an important impact on the development of the surrounding settlements. Aspects of intangible cultural heritage are also strongly present in the Udin Boršt. According to the findings described and the nature- and cultural protection legislation, the outdated ordinance on protecting the Udin Boršt will have to be amended and the area should be safeguarded as part of joint protection of monuments and nature.

Due to its significant geomorphological heritage, the area could also be declared a geopark in order to appropriately protect its karst landscape and forest and to use it for educational purposes. Its future management will have to take into account and connect all the roles described for the Udin Boršt. Especially the different dynamics of natural and man-made processes (Urbanc 2009) and principles within the landscape should be considered. Various stakeholders distributed across three municipalities will have to be persuaded to act together. In order to activate the development potential, effective management needs to be put in place, in which cooperation between local stakeholders and connecting various heritage and other values into a comprehensive range of tourism products is of key importance (Šmid Hribar and Ledinek Lozej 2013).

Finally, future land-use planning in this area will also have to bear in mind the recreational and social role of the forest, which is also indicated by the number of visitors between 2003 and 2012 .

\section{References}

Bohinjec, P. 1998: Pod krivo jelko. Naklo.

Erhartič, B. 2010: Vrednotenje geomorfološke dediščine. Acta geographica Slovenica 50-2. DOI: http://dx.doi.org/ 10.3986/AGS50206

Ferk, M., Lipar, M. 2012: Eogenetske jame v pleistocenskem karbonatnem konglomeratu v Sloveniji. Acta geographica Slovenica 52-1. DOI: http://dx.doi.org/10.3986/AGS52101

Fister, P. 1970: Naselbinske oblike od Jezerskega do Bitenj. Kranjski zbornik. Kranj.

Grad, K., Ferjančič, K. 1976: Tolmač za list Kranj, L 33-65, Osnovna geološka karta SFRJ 1: 100.000. Beograd.

Habič, P. 1981: Tipi krasa na Gorenjskem. Gorenjska, 12. zborovanje slovenskih geografov. Ljubljana.

Kataster jam IZRK 2013: Inštitut za raziskovanje krasa Znanstvenoraziskovalnega centra Slovenske akademije znanosti in umetnosti. Postojna.

Kos, M. 1960: Starejša naselitev na Kranjski ravnini. 900 let Kranja - spominski zbornik. Kranj.

Kranjc, A. 2005: Konglomeratni kras v Sloveniji: zgodovina raziskovanja in poznavanja jam v Udin borštu na Gorenjskem. Acta carsologica 34-2.

Kronika KTD Pod krivo jelko Duplje 1997-2009 (osebna korespondenca). Duplje.

Kronika KTD Pod krivo jelko Duplje 2009-2012 (osebna korespondenca). Duplje.

Kuhar, Š., Šmid, M. 2002: Dupljanska orientacijska pot. Duplje (1:5000). Ljubljana.

Lipar, M., Ferk, M. 2015: Karst pocket Valleys and their implications on Pliocene Quaternary hydrology and climate: Examples from the Nullarbor Plain, Southern Australia. Earth-Science Reviews 150. DOI: http://dx.doi.org/10.1016/j.earscirev.2015.07.002

Lipar, M., Ferk, M. 2011: Eogenetic caves in conglomerate: an example from Udin Boršt, Slovenia. International journal of speleology 40-1. DOI: http://dx.doi.org/10.5038/1827-806X.40.1.7

Mulec, J., Pipan, T. 2005: Vegetacija Udin boršta. Kraške kulturne pokrajine: edinstveni odnos med človekom in kraškim svetom, Udin boršt. Montebelluna.

Odlok o razglasitvi Spominskega parka Udin boršt za zgodovinski in kulturni spomenik. 1985. Uradni vestnik Gorenjske 20/85, 13. december 1985. Kranj.

Operational guidelines for the implementation of the World heritage convention. Internet: http://whc.unesco.org/ archive/opguide12-en.pdf (4.4.2013).

Panizza, M. 2001: Geomorphosites: concepts, methods and example of geomorphological survey. Chinese Science Bulletin 46-1. DOI: http://dx.doi.org/10.1007/BF03187227

Pešpot po Deželi konglomeratnega krasa. Internet: http://eupoti.com/kras/index.htm (10.4.2013).

Polajnar, K. 2008: Ozaveščenost prebivalcev o varovanju mokrišč. Acta geographica Slovenica 48-1. DOI: http://dx.doi.org/10.3986/AGS48105 
Pravilnik o določitvi in varstvu naravnih vrednot. Uradni list Republike Slovenije 111/2004. Ljubljana.

Rajšp, V. 1998: Slovenija na vojaškem zemljevidu 1763-1787; sekcije 151 in 160 (kartografsko gradivo). Ljubljana.

Register nepremične kulturne dediščine. 2014. Ministrstvo za kulturo Republike Slovenije. Internet: http://rkd.situla.org/ (1.3.2014).

Reynard, E., Fontana, G., Kozlik, L., Scapozza, C. 2007: A method for assessing »scientific« and »additional values« of geomorphosites. Geographica Helvetica 62-3.

Smrekar, A., Šmid Hribar, M. Erhartič, B., 2016: Stakeholder conflicts in the Tivoli, Rožnik Hill, and Šiška Hill Protected Landscape Area. Acta geographica Slovenica 56-2. DOI: http://dx.doi.org/10.3986/AGS.895

Šifrer, M. 1969: Kvartarni razvoj Dobrav na Gorenjskem. Geografski zbornik 11.

Širša zavarovana območja. 2014. Agencija Republike Slovenije za okolje. Internet: http://www.arso.gov.si/ narava/zavarovana\%20obmo\%C4\%8Dja/SeznamParkov.htm (1.3.2014).

Šmid Hribar, M. 2009: Intangible aspects of tree heritage: a case study of the 'Bent fir tree' in Udin boršt forest, Slovenia. Woodland cultures in time and space: tales from the past, messages for the future. Athína.

Šmid Hribar, M., Ledinek Lozej, Š. 2013: The role of identification and management of cultural values at development of rural areas. Acta geographica Slovenica 53-2. DOI: http://dx.doi.org/10.3986/AGS53402

The Asia-pacific regional workshop on associative cultural landscapes. 1995: A report by australia ICOMOS to the world heritage committee. Sydney and Blue Mountains, New South Wales.

Urbanc, M. 2009: Pasti in dileme okoljskih poročil: primer Kobilarne Lipica. Geografski vestnik 81-1.

Valvasor, J. V. 1689. Čast in slava Vojvodine Kranjske. Die Ehre Deß Hertzogthums Crain, slovenski ponatis 2009. Ljubljana.

Vpisna knjiga 2012. KTD Pod Krivo jelko. Duplje.

Vrhovnik, I. 1885: Zgodovina Dupljanske fare. Zgodovina far Ljubljanske škofije. Ljubljana.

Zakon o ohranjanju narave. Uradni list Republike Slovenije 96/2004, 61/2006, 63/2007, 32/2008, 8/2010. Ljubljana.

Zakon o varstvu kulturne dediščine. Uradni list Republike Slovenije 16/2008, 123/2008, 8/2011, 30/2011. Ljubljana.

Žlebnik, L. 1978: Kras na konglomeratnih terasah ob Zgornji Savi in njenih pritokih. Geologija 21. 